\title{
Progress toward the Synthesis of Pochonin J
}

\author{
Sydney N. Jackson, Rongson Pongdee* \\ Department of Chemistry, The University of the South, Sewanee, USA \\ Email: *rpongdee@sewanee.edu
}

How to cite this paper: Jackson, S.N. and Pongdee, R. (2019) Progress toward the Synthesis of Pochonin J. International Journal of Organic Chemistry, 9, 96-105. https://doi.org/10.4236/ijoc.2019.92009

Received: May 5, 2019

Accepted: June 10, 2019

Published: June 13, 2019

Copyright $\odot 2019$ by author(s) and Scientific Research Publishing Inc. This work is licensed under the Creative Commons Attribution International License (CC BY 4.0).

http://creativecommons.org/licenses/by/4.0/

\begin{abstract}
The construction of the $\mathrm{C}(1)-\mathrm{C}(5)$ fragment of the resorcylic acid lactone pochonin $\mathrm{J}$ is described. The synthesis is marked by the installation of the cis-1,3-diol moiety in a highly stereoselective manner using Evans' intramolecular base-catalyzed oxyconjugate addition of a hemiacetal-derived nucleophile. The synthetic route presented affords an efficient pathway to the preparation of this critical architectural feature that should facilitate the development of this secondary metabolite as a potential drug candidate.
\end{abstract}

\section{Keywords}

Natural Products, Pochonin J, Resorcylic Acid Lactones

\section{Introduction}

The resorcylic acid lactones (RALs) constitute a structurally diverse family of secondary metabolites possessing a wide-array of biological properties [1] [2]. Representative members of this family of natural products are illustrated in (Figure 1). Pochonin J (4) was isolated from the culture broth of the fungus Pochonia chlamydosporia TF-0480 collected in the Tochigi Prefecture, Japan by Shinonaga in 2009 as part of a screening program to identify inhibitors of the secretory glycoprotein WNT-5A involved in mammalian hair growth [3]. While 4 displayed virtually no activity versus WNT-5A, no additional biological assays were reported. The absence of a detailed biological evaluation of pochonin J (4) was surprising given the fact that many RALs have been shown to be potent inhibitors of heat shock protein 90 (Hsp90) or mitogen-activated protein (MAP) kinases, which are attractive targets for cancer chemotherapy [4] [5].

Architecturally, pochonin J (4) is comprised of a 14-membered macrolactone possessing four chiral centers along the carbon framework [3]. At first glance, the most striking feature of $\mathbf{4}$ is the presence of a trans-fused tetrahydropyran ring, an unusual structural motif among biologically-active secondary metabolites. However, synthetic studies conducted by Jennings have recently called into 
question the validity of the initial structural assignment for pochonin J (4) [6]. Upon completing the synthesis of ent-pochonin J, Jennings and coworkers discovered that several ${ }^{1} \mathrm{H}$ NMR chemical shifts did not align with the reported values for natural pochonin J. Given their findings, Jennings has proposed a structural revision, shown in (Figure 2), based on their consideration of the biosynthetic pathway leading to pochonin $J$ [7]. Their proposal consists of an intermolecular Michael addition at $\mathrm{C}(8)$ leading to epoxy alcohol 6 followed by epoxide opening to furnish cis-tetrahydropyran 7. However, we believe that an alternative biosynthetic pathway may be operative which is also illustrated in (Figure 2). We propose that epoxide opening at the $\mathrm{C}(5)$-position occurs first, presumably involving an active site water molecule to afford anti-1,2-diol 9. Next, an intramolecular Michael addition of the $\mathrm{C}(4)-\mathrm{OH}$ group onto the enone will yield the cis-tetrahydropyran ring in $\mathbf{1 0}$ with the opposite stereochemistry as that proposed by Jennings. Our biosynthetic proposal has merit considering that Piel has recently discovered the existence of an enzymatic domain for the construction of 5- and 6-membered cyclic ethers within polyketides gene clusters [8]. Considering the ambiguity surrounding its proposed structure coupled with the possibility of elucidating its biosynthetic pathway, the lack of a thorough biological evaluation, and our interest in the development of natural products as potential medicinal agents, we elected to embark on a program directed towards the total synthesis of pochonin J.

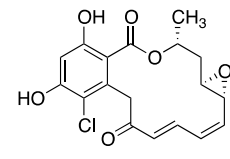

radicicol (1)

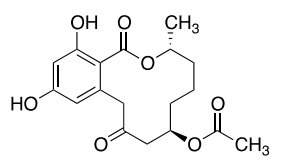

penicimenolide $\mathrm{B}(\mathbf{3})$

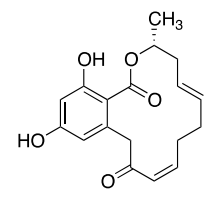

monocillin VI (2)

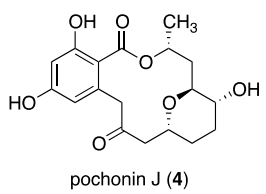

Figure 1. Representative members of the resorcylic acid lactone (RAL) family of natural products.

(A)<smiles>[3H]C(=O)Cc1cc(O)cc(O)c1C(=O)OC[C@@H]1CC[C@@H](O)[C@H](CC(=O)O)O1</smiles>

(B)

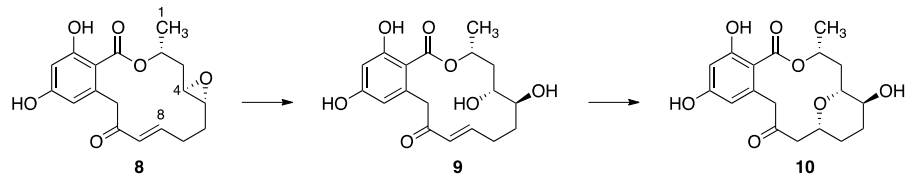

Figure 2. (A) Jennings' biosynthetic proposal for tetrahydropyran ring closure; (B) Pongdee's Biosynthetic Proposal for tetrahydropyran ring closure. 


\section{Results and Discussion}

Our retrosynthetic analysis for pochonin $J$ is illustrated in (Figure 3). From the outset, we envisioned a modular synthetic approach that would allow us to efficiently set either configuration of each chiral center. This flexibility would enable us to rapidly construct all of the possible diastereomers for pochonin J in our initial efforts focused on establishing its correct three-dimensional structure. For our synthetic approach, we viewed the construction of the $\mathrm{C}(1)-\mathrm{C}(5)$ fragment 10 as a key objective since the stereochemistry present in this five carbon unit would assist in controlling the introduction of future chiral centers in pochonin J. Our work towards the synthesis of 10 is described below.

Our synthetic approach towards 13 originated from commercially-available ethyl 3(R)-hydroxybutyrate (14) as depicted in (Scheme 1). First, treatment of 14 with trimethylaluminum $\left(\mathrm{Me}_{3} \mathrm{Al}\right)$ and $\mathrm{N}, \mathrm{O}$-dimethylhydroxylamine hydrochloride furnished Weinreb amide 15 in excellent yield [9] [10] [11]. At this juncture, we envisioned addition of a suitable organometallic reagent that would provide direct access to the $\mathrm{C}(1)-\mathrm{C}(5)$ fragment of pochonin J following oxidative cleavage of the resulting $\pi$-bond. However, after exhaustive experimentation we were surprisingly unable to isolate any products from the reaction of $15 \mathrm{em}$ ploying a variety of alkenyl or alkynyl nucleophiles.

With our initial efforts stalled, we redirected our efforts to elaborating Weinreb amide 15 to a suitably protected form of the $\mathrm{C}(1)-\mathrm{C}(5)$ fragment of pochonin $\mathrm{J}$ as shown in (Scheme 2). Protection of the free alcohol in 15 as its tert-butyldiphenylsilyl (TBDPS) ether using the corresponding silyl chloride and Hünig's base $\left(i\right.$ - $\left.\mathrm{Pr}_{2} \mathrm{NEt}\right)$ provided silyl ether 19 in excellent yield. Next, reduction of the Weinreb amide functional group employing diisobutylaluminum hydride (DIBALH) followed by Masamune-Roush olefination of the resultant aldehyde afforded ethyl enoate $\mathbf{2 0}$ in good overall yield for the two-step process [12] [13]. At this stage, we were primed to install the requisite stereochemistry at $\mathrm{C}(4)$. To this end, deprotection of enoate $\mathbf{2 0}$ under standard conditions using tetrabutylammonium fluoride (TBAF) liberated the free hydroxyl group which underwent an Evans' oxyconjugate addition with benzaldehyde ( $\mathrm{PhCHO}$ ) to form benzylidene 21 [14] [15] [16]. Then, reduction of the ester moiety by treatment of 21 with lithium aluminum hydride afforded alcohol 22 in excellent yield followed by smooth conversion of the resultant primary alcohol to terminal olefin $23 \mathrm{em}$ ploying the Grieco procedure [17] [18]. Lastly, oxidative cleavage of the 23 utilizing a two-step process involving osmium tetroxide and sodium periodate furnished the desired $\mathrm{C}(1)-\mathrm{C}(5)$ fragment 24.

\section{Conclusions}

In summary, we have developed a synthesis of the $\mathrm{C}(1)-\mathrm{C}(5)$ fragment of pochonin $\mathrm{J}$ in only eleven linear steps beginning with ethyl $3(R)$-hydroxybutyrate (14). A key step involved in our approach is the use of an Evans' oxyconjugate addition reaction to install the cis-1,3-diol motif with high stereoselectivity. The 


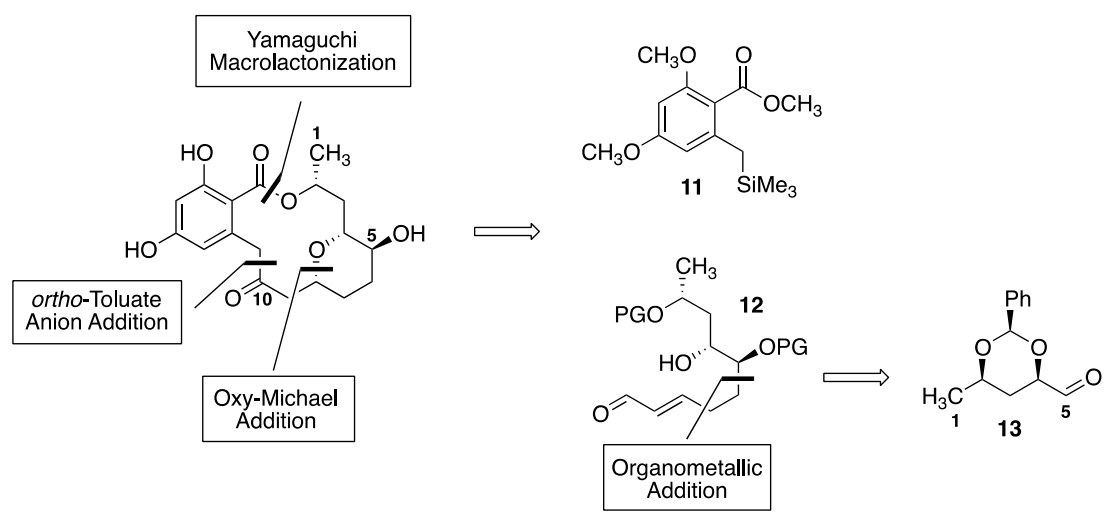

Figure 3. Retrosynthetic Analysis for Pochonin J.

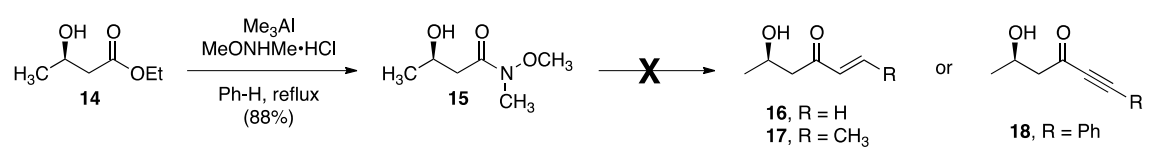

Scheme 1. Initial approach to C(1)-C(5) fragment of pochonin J.
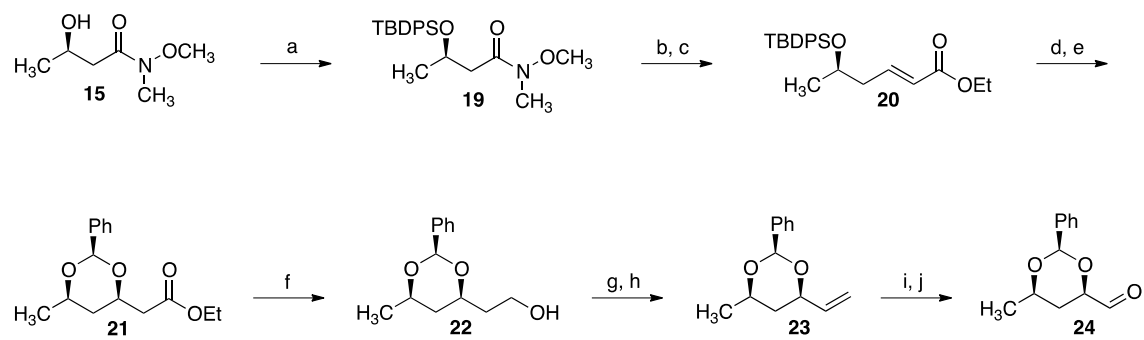

Scheme 2. Reagents and conditions: (a) TBDPS-CI, $i-\mathrm{Pr}_{2} \mathrm{NEt}, \mathrm{CH}_{2} \mathrm{Cl}_{2}, 0^{\circ} \mathrm{C}$ to RT, $95 \%$; (b) DIBALH, $\mathrm{Et}_{2} \mathrm{O},-78^{\circ} \mathrm{C}$; (c) (EtO) ${ }_{2} \mathrm{P}(\mathrm{O}) \mathrm{CH}_{2} \mathrm{CO}_{2} \mathrm{Et}, i-\mathrm{Pr}_{2} \mathrm{NEt}, \mathrm{LiCl}, \mathrm{CH}_{3} \mathrm{CH}, 90 \%$ over two steps; (d) TBAF, THF, 80\%; (e) $t$-BuOK, PhCHO, THF, $0^{\circ} \mathrm{C}, 61 \%$; (f) $\mathrm{LiAIH}_{4}, \mathrm{THF}, 0^{\circ} \mathrm{C}$, 92\%; (g) $o-\mathrm{NO}_{2}-\mathrm{PhSeCN}, \mathrm{Bu}_{3} \mathrm{P}$, THF; (h) $30 \% \mathrm{H}_{2} \mathrm{O}_{2}$, THF, $74 \%$ over two steps; (i) $\mathrm{OsO}_{4}$, $\mathrm{THF} / \mathrm{Me}_{2} \mathrm{CO} / \mathrm{pH} 7$ Buffer; (j) $\mathrm{NalO}_{4}$, THF/pH 7 Buffer, $60 \%$ over two steps.

route that we have developed provides a new approach to access a critical structural feature that is present in many resorcylic acid lactone natural products and should find wide application for researchers engaged in this area of study. Furthermore, the efficiency of our synthetic scheme will allow us to explore our proposed biosynthetic proposal for pochonin $\mathrm{J}$ as well as perform additional biological testing. Our efforts along those lines will be presented in due course.

\section{Experimental}

General Procedures. All non-aqueous reactions were carried out in flame-dried round-bottomed flasks under an atmosphere of argon. Air- and moisture-sensitive liquids were transferred by oven-dried stainless-steel needles. Reactions were conducted at room temperature (approximately $22^{\circ} \mathrm{C}$ ) unless otherwise noted. Flash chromatography was performed with the indicated solvents using standard grade silica gel SiliaFlash ${ }^{\oplus}$ P60 (particle size 230 - 400 mesh) from Silicycle Incorporated. Reactions were monitored by thin-layer chromatography (TLC) us- 
ing $0.25 \mathrm{~mm}$ thickness precoated glass-backed silica gel plates containing F254 indicator manufactured by Sorbent Technologies. Visualization was accomplished with UV light and ethanolic p-anisaldehyde, phosphomolybdic acid, or potassium permanganate stain solution followed by charring on a hot plate. Yields refer to chromatographically and spectroscopically pure compounds (>95\%) unless otherwise stated.

Materials. Anhydrous reaction solvents were purchased from Sigma-Aldrich or Acros. All other commercial reagents were purchased from either Sigma-Aldrich or Acros and used as received without additional purification.

Instrumentation. Infrared spectra were recorded using a Perkin-Elmer Spectrum One FT-IR spectrometer equipped with a Universal ATR Sampling Accessory and are reported in terms of frequency of absorption $\left(\mathrm{cm}^{-1}\right) .{ }^{1} \mathrm{H}$ NMR spectra were measured at $400 \mathrm{MHz}$ on a JEOL ECS-400 spectrometer and are reported relative to deuterated solvent signals. Data for ${ }^{1} \mathrm{H}$ NMR spectra are reported as follows: chemical shift $(\delta \mathrm{ppm})$, multiplicity ( $\mathrm{s}=$ singlet, $\mathrm{d}=$ doublet, $\mathrm{t}$ $=$ triplet, $\mathrm{bt}=$ broad triplet, $\mathrm{q}=$ quartet, $\mathrm{dd}=$ doublet of doublets, $\mathrm{qt}=$ quartet of triplets, sex $=$ sextuplet, $\mathrm{m}=$ multiplet, app $=$ apparent), coupling constants $(\mathrm{Hz})$, and integration. ${ }^{13} \mathrm{C}$ NMR spectra were measured at $100 \mathrm{MHz}$ on a JEOL ECS-400 spectrometer and are reported relative to deuterated solvent signals. Accurate mass measurements were performed by Dr. William Boggess of the Mass Spectrometry and Proteomics Facility at the University of Notre Dame. Optical rotations were measured using a Jasco P-2000 digital polarimeter and are reported as follows $[\alpha]_{\lambda}^{T}$, (c g/100 mL, solvent).

Weinreb amide (19): To a solution of alcohol $15(3.50 \mathrm{~g}, 23.9 \mathrm{mmol})$ in anhydrous $\mathrm{CH}_{2} \mathrm{Cl}_{2}$ at $0^{\circ} \mathrm{C}$ was added $i$ - $\mathrm{Pr}_{2} \mathrm{NEt}(7.80 \mathrm{~mL}, 47.8 \mathrm{mmol})$ and TBDPSCl $(8.00 \mathrm{~mL}, 26.3 \mathrm{mmol})$ and the reaction was warmed to room temperature overnight. The reaction was poured into saturated aqueous $\mathrm{NaHCO}_{3}(100 \mathrm{~mL})$ and extracted with $\mathrm{CH}_{2} \mathrm{Cl}_{2}(3 \times 100 \mathrm{~mL})$. The combined organic layers were washed with $1.0 \mathrm{M} \mathrm{HCl}(1 \times 100 \mathrm{~mL})$ and brine $(1 \times 100 \mathrm{~mL})$, dried over $\mathrm{Na}_{2} \mathrm{SO}_{4}$, filtered, and concentrated in vacuo. The residue was purified by flash column chromatography (5:1 hexanes:EtOAc) to afford $9.38 \mathrm{~g}$ of 19 as a clear oil (95\%): $[\alpha]_{D}^{22}=-6.47\left(c=0.121, \mathrm{CHCl}_{3}\right) ;{ }^{1} \mathrm{H} \mathrm{NMR}\left(400 \mathrm{MHz}, \mathrm{CDCl}_{3}\right) \delta 7.70-7.67(\mathrm{~m}$, $4 \mathrm{H}), 7.42-7.33(\mathrm{~m}, 6 \mathrm{H}), 4.41(\operatorname{app} \mathrm{sex}, J=6.4 \mathrm{~Hz}, 1 \mathrm{H}), 3.58(\mathrm{~s}, 3 \mathrm{H}), 3.11(\mathrm{~s}, 3 \mathrm{H})$, $2.80(\mathrm{dd}, J=14.2,6.4 \mathrm{~Hz}, 1 \mathrm{H}), 2.41(\mathrm{dd}, J=14.2,6.4 \mathrm{~Hz}, 1 \mathrm{H}), 1.11(\mathrm{~d}, J=6.0 \mathrm{~Hz}$, $3 \mathrm{H}), 1.03$ (s, 9H); ${ }^{13} \mathrm{C}$ NMR (100 MHz) $\delta 172.0,135.8,135.7,134.4,133.9,129.5$, 129.4, 127.5, 127.4, 66.9, 61.1, 41.7, 31.8, 26.8, 23.7, 19.1; IR (neat): 2963, 2932, 2857, 1660; HRMS (ESI) calcd for $\mathrm{C}_{22} \mathrm{H}_{32} \mathrm{NO}_{3} \mathrm{Si}(\mathrm{M}+\mathrm{H})^{+}$386.2151, found 386.2146 .

Ethyl enoate (20): To a solution of Weinreb amide $19(1.00 \mathrm{~g}, 2.69 \mathrm{mmol})$ in anhydrous $\mathrm{Et}_{2} \mathrm{O}(15.0 \mathrm{~mL})$ at $-78^{\circ} \mathrm{C}$ was added DIBALH $(2.95 \mathrm{~mL}$ of a $1.0 \mathrm{M}$ solution in hexanes, $2.95 \mathrm{mmol}$ ) and the reaction continued stirring for $30 \mathrm{~min}$. The reaction was quenched by the addition of $1.0 \mathrm{M} \mathrm{HCl}(20 \mathrm{~mL})$ and extracted with EtOAc $(3 \times 30 \mathrm{~mL})$. The combined organic layers were washed with brine 
$(1 \times 35 \mathrm{~mL})$, filtered through a pad of Celite using EtOAc $(200 \mathrm{~mL})$, dried over $\mathrm{Na}_{2} \mathrm{SO}_{4}$, filtered, and concentrated in vacuo to provide $0.850 \mathrm{~g}$ of crude aldehyde that was used without further purification.

To a mixture of $\mathrm{LiCl}(0.230 \mathrm{~g}, 5.36 \mathrm{mmol})$ in anhydrous $\mathrm{CH}_{3} \mathrm{CN}(39.0 \mathrm{~mL})$ at room temperature was added triethylphosphonoacetate $(0.740 \mathrm{~mL}, 3.72 \mathrm{mmol})$, i-Pr ${ }_{2} \mathrm{NEt}(0.560 \mathrm{~mL}, 3.50 \mathrm{mmol})$, crude aldehyde $(0.760 \mathrm{~g}, 2.60 \mathrm{mmol})$, and the reaction continued stirring overnight. The reaction was quenched by the addition of $1.0 \mathrm{M} \mathrm{HCl}(30 \mathrm{~mL})$ and extracted with EtOAc $(3 \times 25 \mathrm{~mL})$. The combined organic layers were washed with brine $(1 \times 35 \mathrm{~mL})$, filtered through a pad of Celite, and concentrated in vacuo. The residue was purified by flash column chromatography (19:1 hexanes:EtOAc) to afford $0.960 \mathrm{~g}$ (90\% from Weinreb amide 19) of 20 as a clear oil (90\%): $[\alpha]_{D}^{22}=+25.1\left(c=0.138, \mathrm{CHCl}_{3}\right) ;{ }^{1} \mathrm{H} \mathrm{NMR}$ $\left(400 \mathrm{MHz}, \mathrm{CDCl}_{3}\right) \delta 7.68-7.65(\mathrm{~m}, 4 \mathrm{H}), 7.42-7.34(\mathrm{~m}, 6 \mathrm{H}), 6.91(\mathrm{dt}, J=15.6$, $7.6 \mathrm{~Hz}, 1 \mathrm{H}), 5.75(\mathrm{dt}, J=15.6,1.2 \mathrm{~Hz}, 1 \mathrm{H}), 4.17(\mathrm{q}, J=3.2 \mathrm{~Hz}, 2 \mathrm{H}), 3.95($ app sex, $J=6.0 \mathrm{~Hz}, 1 \mathrm{H}), 2.36-2.24(\mathrm{~m}, 2 \mathrm{H}), 1.27(\mathrm{t}, J=7.2 \mathrm{~Hz}, 3 \mathrm{H}), 1.08(\mathrm{~d}, J=6.4$ $\mathrm{Hz}, 3 \mathrm{H}), 1.05$ (s, 9H); ${ }^{13} \mathrm{C}$ NMR (100 MHz) $\delta$ 166.3, 145.5, 135.8, 134.2, 133.9, $129.6,129.5,127.5,127.4,123.3,68.4,60.1,42.0,26.9,23.1,19.1,14.2$; IR (neat): 2964, 2931, 2896, 1719; HRMS (ESI) calcd for $\mathrm{C}_{24} \mathrm{H}_{33} \mathrm{O}_{3} \mathrm{Si}(\mathrm{M}+\mathrm{H})^{+}$397.2199, found 397.2193.

Benzylidene (21): To a solution of enoate $20(1.50 \mathrm{~g}, 3.78 \mathrm{mmol})$ in anhydrous THF $(15.0 \mathrm{~mL})$ at room temperature was added TBAF $(4.50 \mathrm{~mL}$ of a $1.0 \mathrm{M}$ solution in THF, $4.50 \mathrm{mmol}$ ) and the reaction continued stirring overnight. The reaction was quenched by the addition of saturated aqueous $\mathrm{NH}_{4} \mathrm{Cl}(45 \mathrm{~mL})$, extracted with EtOAc $(3 \times 35 \mathrm{~mL})$. The combined organic layers were washed with brine $(1 \times 35 \mathrm{~mL})$, dried over $\mathrm{Na}_{2} \mathrm{SO}_{4}$, filtered, and concentrated in vacuo. The residue was purified by flash column chromatography (3:1 hexanes:EtOAc) to afford $0.479 \mathrm{~g}$ of alcohol as a clear oil (80\%): $[\alpha]_{D}^{22}=-9.71\left(c=0.116, \mathrm{CHCl}_{3}\right)$; ${ }^{1} \mathrm{H}$ NMR $\left(400 \mathrm{MHz}, \mathrm{CDCl}_{3}\right) \delta 6.93(\mathrm{dt}, J=16.0,7.2 \mathrm{~Hz}, 1 \mathrm{H}), 5.87(\mathrm{dt}, J=16.0$, $1.2 \mathrm{~Hz}, 1 \mathrm{H}), 4.15(\mathrm{q}, J=7.2 \mathrm{~Hz}, 2 \mathrm{H}), 3.94($ app sex, $J=6.4 \mathrm{~Hz}, 1 \mathrm{H}), 2.35-2.31$ (m, 2H), 1.73 (bs, $1 \mathrm{H}), 1.25$ (t, $J=6.8 \mathrm{~Hz}, 3 \mathrm{H}), 1.21(\mathrm{~d}, J=6.0 \mathrm{~Hz}, 3 \mathrm{H}) ;{ }^{13} \mathrm{C} \mathrm{NMR}$ (100 MHz) $\delta 166.3,144.9,123.9,66.7,60.3,41.7,23.1,14.2$; IR (neat): 3454, 2974, 2931, 1716, 1699; HRMS (ESI) calcd for $\mathrm{C}_{8} \mathrm{H}_{14} \mathrm{NaO}_{3}(\mathrm{M}+\mathrm{Na})^{+} 181.0841$, found 181.0835 .

To a solution of alcohol $(0.997 \mathrm{~g}, 6.38 \mathrm{mmol})$ in anhydrous THF $(64.0 \mathrm{~mL})$ at $0^{\circ} \mathrm{C}$ was added benzaldehyde $(0.71 \mathrm{~mL}, 7.02 \mathrm{mmol})$ and potassium tert-butoxide $(0.072 \mathrm{~g}, 0.638 \mathrm{mmol})$ and the reaction continued stirring for $15 \mathrm{mins}$. Over the course of $30 \mathrm{mins}$, additional potassium tert-butoxide $(0.072 \mathrm{~g}, 0.638 \mathrm{mmol})$ was added at $15 \mathrm{~min}$ intervals at which time the reaction was allowed to warm to room temperature overnight. The reaction was quenched by the addition of $\mathrm{pH}$ 7 buffer $(50 \mathrm{~mL})$ and extracted with EtOAc $(3 \times 50 \mathrm{~mL})$. The combined organic layers were washed with brine $(1 \times 50 \mathrm{~mL})$, dried over $\mathrm{Na}_{2} \mathrm{SO}_{4}$, filtered, and concentrated in vacuo. The residue was purified by flash column chromatography (19:1 hexanes:EtOAc) to afford $1.02 \mathrm{~g}$ of 21 as an off-white solid (61\%): 
$[\alpha]_{D}^{22}=-9.22\left(c=0.033, \mathrm{CHCl}_{3}\right) ;{ }^{1} \mathrm{H} \mathrm{NMR}\left(400 \mathrm{MHz}, \mathrm{C}_{6} \mathrm{D}_{6}\right) \delta 7.63-7.61(\mathrm{~m}$, $1 \mathrm{H}), 7.15-7.11(\mathrm{~m}, 3 \mathrm{H}), 7.07-7.03(\mathrm{~m}, 1 \mathrm{H}), 5.38(\mathrm{~s}, 1 \mathrm{H}), 4.14-4.07(\mathrm{~m}, 1 \mathrm{H})$, $3.93-3.87(\mathrm{~m}, 2 \mathrm{H}), 3.47-3.40(\mathrm{~m}, 1 \mathrm{H}), 2.56(\mathrm{dd}, J=15.6,7.6 \mathrm{~Hz}, 1 \mathrm{H}), 2.20(\mathrm{dd}$, $J=15.6,7.6 \mathrm{~Hz}, 1 \mathrm{H}), 1.16-1.11(\mathrm{~m}, 2 \mathrm{H}), 1.04(\mathrm{~d}, J=6.4 \mathrm{~Hz}, 3 \mathrm{H}), 0.89(\mathrm{t}, J=6.8$ $\mathrm{Hz}, 2 \mathrm{H}) ;{ }^{13} \mathrm{C}$ NMR $(100 \mathrm{MHz}) \delta 171.5,140.8,129.8,129.1,128.0,102.2,74.6$, 73.8, 61.5, 42.4, 39.3, 22.7, 15.3; IR (neat): 2980, 2911, 2876, 1724; HRMS (ESI) calcd for $\mathrm{C}_{15} \mathrm{H}_{21} \mathrm{O}_{4}(\mathrm{M}+\mathrm{H})^{+}$265.1440, found 265.1434.

Alcohol (22): To a solution of benzylidene $21(0.627 \mathrm{mg}, 2.37 \mathrm{mmol})$ in anhydrous THF $(38.0 \mathrm{~mL})$ at $0^{\circ} \mathrm{C}$ was added lithium aluminum hydride $(2.84 \mathrm{~mL}$ of a $1.0 \mathrm{M}$ solution in THF, $2.84 \mathrm{mmol}$ ) and the reaction continued stirring for 1 $\mathrm{hr}$. The reaction was quenched by the addition of EtOAc $(70.0 \mathrm{~mL})$ and warmed to room temperature at which time water $(20.0 \mathrm{~mL})$ was added and the mixture was stirred vigorously for $5 \mathrm{~min}$. The reaction was dried with $\mathrm{Na}_{2} \mathrm{SO}_{4}$, filtered using EtOAc (1.0 L), and concentrated in vacuo. The residue was purified by flash column chromatography (4:1 hexanes:EtOAc) to afford $0.527 \mathrm{~g}$ of 22 as a white solid (92\%): $[\alpha]_{D}^{22}=-16.9\left(c=0.020, \mathrm{CHCl}_{3}\right) ;{ }^{1} \mathrm{H} \mathrm{NMR}\left(400 \mathrm{MHz}, \mathrm{C}_{6} \mathrm{D}_{6}\right)$ $\delta 7.60-7.58(\mathrm{~m}, 2 \mathrm{H}), 7.15,7.03(\mathrm{~m}, 3 \mathrm{H}), 5.33(\mathrm{~s}, 1 \mathrm{H}), 3.66-3.59(\mathrm{~m}, 2 \mathrm{H}), 3.56$ $3.50(\mathrm{~m}, 1 \mathrm{H}), 3.49-3.41(\mathrm{~m}, 1 \mathrm{H}), 1.84(\mathrm{bs}, 1 \mathrm{H}), 1.69-1.61(\mathrm{~m}, 1 \mathrm{H}), 1.46-1.39$ $(\mathrm{m}, 1 \mathrm{H}), 1.19-1.10(\mathrm{~m}, 1 \mathrm{H}), 1.07(\mathrm{~d}, J=6.0 \mathrm{~Hz}, 3 \mathrm{H}), 0.93(\mathrm{dt}, J=12.8,2.0 \mathrm{~Hz}$, $1 \mathrm{H}) ;{ }^{13} \mathrm{C}$ NMR (100 MHz) $\delta 139.0,128.0,127.1,125.9,100.3,74.5,72.1,58.8$, 38.0, 37.9, 20.9; IR (neat): 3290, 2963, 2921, 1340; HRMS (ESI) calcd for $\mathrm{C}_{13} \mathrm{H}_{19} \mathrm{O}_{3}(\mathrm{M}+\mathrm{H})^{+}$223.1334, found 223.1329.

Alkene (23): To a solution of alcohol $22(0.150 \mathrm{~g}, 0.675 \mathrm{mmol})$ in anhydrous THF $(7.0 \mathrm{~mL})$ at room temperature was added $o$-nitrophenylselenocyanate $(0.169 \mathrm{~g}, 0.743 \mathrm{mmol})$ and tributylphosphine $(0.202 \mathrm{~mL}, 0.810 \mathrm{mmol})$ and the reaction continued stirring for 30 mins. The solvent was removed in vacuo to afford $0.235 \mathrm{~g}$ of selenide as an orange solid.

To a solution of selenide $(0.235 \mathrm{~g}, 0.578 \mathrm{mmol})$ in anhydrous THF $(8.0 \mathrm{~mL})$ at room temperature was added hydrogen peroxide $(0.589 \mathrm{~mL}$ of a $30 \%$ solution in water, $5.20 \mathrm{mmol}$ ) and the reaction continued stirring overnight. The reaction was poured into $\mathrm{Et}_{2} \mathrm{O}(40 \mathrm{~mL})$ and $10 \% \mathrm{NaOH}(11 \mathrm{~mL})$ and extracted with $\mathrm{Et}_{2} \mathrm{O}$ $(1 \times 15 \mathrm{~mL})$. The combined organic layers were washed with $10 \% \mathrm{NaOH}(3 \times 10$ $\mathrm{mL})$, brine $(10 \mathrm{~mL})$, dried over $\mathrm{Na}_{2} \mathrm{SO}_{4}$, filtered, and concentrated in vacuo. The residue was purified by flash column chromatography (100:1 hexanes:EtOAc) to afford $0.102 \mathrm{~g}$ of 23 as a yellow oil $(74 \%):[\alpha]_{D}^{22}=-11.9\left(c=0.010, \mathrm{CHCl}_{3}\right) ;{ }^{1} \mathrm{H}$ NMR (400 MHz, $\left.\mathrm{C}_{6} \mathrm{D}_{6}\right) \delta 7.66-7.64(\mathrm{~m}, 2 \mathrm{H}), 7.15-7.03(\mathrm{~m}, 3 \mathrm{H}), 5.77$ (ddd, $J=$ 16.0, 10.6, $5.2 \mathrm{~Hz}, 1 \mathrm{H}), 5.38(\mathrm{~s}, 1 \mathrm{H}), 5.22(\mathrm{dt}, J=17.21 .6 \mathrm{~Hz}, 1 \mathrm{H}), 4.96(\mathrm{dt}, J=$ $10.4,1.6 \mathrm{~Hz}, 1 \mathrm{H}), 3.92-3.87(\mathrm{~m}, 1 \mathrm{H}), 3.47-3.39(\mathrm{~m}, 1 \mathrm{H}), 1.30-1.21(\mathrm{~m}, 1 \mathrm{H})$, $1.05(\mathrm{~d}, J=6.0 \mathrm{~Hz}, 3 \mathrm{H}), 1.03(\mathrm{dt}, J=12.8,2.4 \mathrm{~Hz}, 1 \mathrm{H}) ;{ }^{13} \mathrm{C} \mathrm{NMR}(100 \mathrm{MHz}) \delta$ 140.8, 139.7, 129.8, 129.0, 128.0, 115.7, 102.1, 78.2, 73.9, 39.7, 22.8; IR (neat): 2974, 2844, 1333; HRMS (ESI) calcd for $\mathrm{C}_{13} \mathrm{H}_{17} \mathrm{O}_{2}(\mathrm{M}+\mathrm{H})^{+}$205.1229, found 205.1223.

Aldehyde 24: To a solution of olefin $23(0.050 \mathrm{~g}, 0.245 \mathrm{mmol})$ in THF (0.75 
$\mathrm{mL})$, acetone $(0.75 \mathrm{~mL})$, and $\mathrm{pH} 7$ Buffer $(0.75 \mathrm{~mL})$ at room temperature was added $N$-methylmorpholine- $N$-oxide $(0.086 \mathrm{~g}, 0.735 \mathrm{mmol})$ and $\mathrm{OsO}_{4}(0.024 \mathrm{~mL}$ of a $2.5 \%$ solution in tert-butanol, $0.0122 \mathrm{mmol}$ ) and the reaction continued stirring overnight. The reaction was cooled to $0^{\circ} \mathrm{C}$ and saturated aqueous $\mathrm{NaHSO}_{3}$ $(10 \mathrm{~mL})$ was added. The ice bath was removed and the mixture was stirred for an additional $30 \mathrm{~min}$, then was extracted with EtOAc $(3 \times 10 \mathrm{~mL})$. The combined organic layers were washed with brine $(1 \times 10 \mathrm{~mL})$, dried over $\mathrm{Na}_{2} \mathrm{SO}_{4}$, filtered, and concentrated in vacuo to provide $0.058 \mathrm{~g}$ of crude diol that was used without further purification.

To a solution of the crude diol $(0.058 \mathrm{~g}, 0.243 \mathrm{mmol})$ in anhydrous THF (1.5 $\mathrm{mL})$ and $\mathrm{pH} 7 \mathrm{Buffer}(0.50 \mathrm{~mL})$ was added $\mathrm{NaIO}_{4}(0.062 \mathrm{~g}, 0.292 \mathrm{mmol})$ and the reaction continued stirring for $3 \mathrm{hr}$. The reaction was diluted with EtOAc (10 $\mathrm{mL}$ ) and washed with saturated aqueous $\mathrm{NaHCO}_{3}$. The combined organic layers were dried over $\mathrm{NaSO}_{4}$, filtered, and concentrated in vacuo. The residue was purified by flash column chromatography (1:2 hexanes:EtOAc) to afford $0.030 \mathrm{~g}$ of 24 as a yellow oil $(60 \%):[\alpha]_{D}^{22}=+26.4\left(c=0.007, \mathrm{CHCl}_{3}\right) ;{ }^{1} \mathrm{H} \mathrm{NMR}(400 \mathrm{MHz}$, $\left.\mathrm{C}_{6} \mathrm{D}_{6}\right) \delta 9.39(\mathrm{~s}, 1 \mathrm{H}), 7.56-7.54(\mathrm{~m}, 2 \mathrm{H}), 7.16-7.05(\mathrm{~m}, 3 \mathrm{H}), 5.14(\mathrm{~s}, 1 \mathrm{H}), 3.49$ $(\mathrm{dd}, J=12.0,3.6 \mathrm{~Hz}, 1 \mathrm{H}), 3.26-3.18(\mathrm{~m}, 1 \mathrm{H}), 1.19-1.04(\mathrm{~m}, 2 \mathrm{H}), 0.92(\mathrm{~d}, J=6.0$ $\mathrm{Hz}, 3 \mathrm{H}) ;{ }^{13} \mathrm{C} \mathrm{NMR}(100 \mathrm{MHz}) \delta 199.5,138.3,128.7,128.1,126.4,100.5,79.9$, 72.2, 32.5, 21.1; IR (neat): 2971, 2927, 1737, 1454; HRMS (ESI) calcd for $\mathrm{C}_{12} \mathrm{H}_{14} \mathrm{O}_{3}(\mathrm{M}+\mathrm{H})^{+}$207.1021, found 207.1016.

\section{Acknowledgements}

We gratefully acknowledge financial support from the National Institute of Allergy and Infectious Diseases (R15, AI084075-02), the Donors of the American Chemical Society Petroleum Research Fund (PRF 52168-UR1), and the American Philosophical Society for a Franklin Research Grant. Additionally, we thank the National Science Foundation, as part of its Major Research Instrumentation (MRI) Program (CHE-1126231), for the acquisition of a JEOL ECS-400 Nuclear Magnetic Resonance Spectrometer. Accurate mass measurements were performed by Dr. William Boggess of the Mass Spectrometry and Proteomics Facility at the University of Notre Dame.

\section{Conflicts of Interest}

The authors declare no conflicts of interest regarding the publication of this paper.

\section{References}

[1] Winssinger, N. and Barluenga, S. (2007) Chemistry and Biology of Resorcylic Acid Lactones. Chemical Communications, 43, 22-36. https://doi.org/10.1039/B610344H

[2] Jana, N. and Nanda, S. (2018) Resorcylic Acid Lactones (RALs) and Their Structural Congeners: Recent Advances in Their Biosynthesis, Chemical Synthesis and Biology. New Journal of Chemistry, 42, 17803-17873.

https://doi.org/10.1039/C8NJ02534G 
[3] Shinonaga, H., Kawamura, Y., Ikeda, A., Aoki, M., Sakai, N., Fujimoto, N. and Kawashima, A. (2009) The Search for a Hair-Growth Stimulant: New Radicicol Analogues as WNT-5A Expression Inhibitors from Pochonia chlamydosporia var. chlamydosporia. Tetrahedron Letters, 50, 108-110. https://doi.org/10.1016/j.tetlet.2008.10.099

[4] Patocka, J., Soukup, O. and Kuca, K. (2013) Resorcylic Acid Lactones as the Protein Kinase Inhibitors, Naturally Occuring Toxins. Mini-Reviews in Medicinal Chemistry, 13, 1873-1878. https://doi.org/10.2174/13895575113136660096

[5] Zhao, A., Lee, S.H., Moiena, M., Jenkins, R.G., Patrick, D.R., Huber, H.E., Goetz, M.A., Hensens, O.D., Zink, D.L., Viella, D., Dombrowski, A.W., Lingham, R.B. and Huang, L. (1999) Resorcylic Acid Lactones: Naturally Occurring Potent and Selective Inhibitors of MEK. The Journal of Antibiotics, 52, 1086-1094.

https://doi.org/10.7164/antibiotics.52.1086

[6] Martinez-Solorio, D., Belmore, K.A. and Jennings, M.P. (2011) Synthesis of the Purported Ent-Pochonin J Structure Featuring a Stereoselective Oxocarbenium Allylation. The Journal of Organic Chemistry, 76, 3898-3908. https://doi.org/10.1021/jo200332d

[7] Martinez-Solorio, D. (2011) Syntheses of C-Glycoside Natural Products via Oxocarbenium Cationic Intermediates. PhD Dissertation, University of Alabama, Tuscaloosa.

[8] Pöplau, P., Frank, S., Morinaka, B.I. and Piel, J. (2013) An Enzymatic Domain for the Formation of Cyclic Ethers in Complex Polyketides. Angewandte Chemie International Edition, 52, 13215-13218. https://doi.org/10.1002/anie.201307406

[9] Nelson, S.G., Cheung, W.S., Kassicl, A.J. and Hilfiker, M.A. (2002) A de Novo Enantioselective Total Synthesis of (-)-Laulimalide. Journal of the American Chemical Society, 124, 13654-13655. https://doi.org/10.1021/ja028019k

[10] Denmark, S.E. and Fujimori, S. (2002) The Effects of a Remote Stereogenic Center in the Lewis Base-Catalyzed Aldol Additions of Chiral Trichlorosilyl Enolates. Organic Letters, 4, 3477-3480. https://doi.org/10.1021/ol026594n

[11] Nahm, S. and Weinreb, S.M. (1981) N-Methoxy-N-Methylamides as Effective Acylating Agents. Tetrahedron Letters, 22, 3815-3818. https://doi.org/10.1016/S0040-4039(01)91316-4

[12] Blanchette, M.A., Choy, W., Davis, J.T., Essenfeld, A.P., Masamune, S., Roush, W.R. and Sakai, T. (1984) Horner-Wadsworth-Emmons Reaction: Use of Lithium Chloride and an Amine Forbase-Sensitive Compounds. Tetrahedron Letters, 25, 2183 2186. https://doi.org/10.1016/S0040-4039(01)80205-7

[13] Yamini, V., Reddy, K.M., Krishna, A.S., Lakshmi, J.K. and Ghosh, S. (2019) Formal Total Synthesis of Mandelalide A. Journal of Chemical Sciences, 131, 25. https://doi.org/10.1007/s12039-019-1600-2

[14] Smith, C.M. and O’Doherty, G.A. (2003) Enantioselective Syntheses of Cryptocarya Triacetate, Cryptocaryolone, and Cryptocaryolone Diacetate. Organic Letters, 5, 1959-1962. https://doi.org/10.1021/ol0345529

[15] Garass, S.D., Hunter, T.J. and O’Doherty, G.A. (2002) An Enantioselective Synthesis of Tarchonanthuslactone. The Journal of Organic Chemistry, 67, 2682-2685. https://doi.org/10.1021/jo0163400

[16] Evans, D.A. and Gauchet-Prunet, J.A. (1993) Diastereoselective Synthesis of Protected Syn 1,3-diols by Base-Catalyzed Intramolecular Conjugate Addition of $\mathrm{He}$ miacetal-Derived Alkoxide Nucleophiles. The Journal of Organic Chemistry, 58, 2446-2448. https://doi.org/10.1021/jo00061a018 
[17] Grieco, P.A., Gilman, S. and Nishizawa, M. (1976) Organoselenium Chemistry. A Facile One-Step Synthesis of Alkyl Aryl Selenides from Alcohols. The Journal of Organic Chemistry, 41, 1485-1486. https://doi.org/10.1021/jo00870a052

[18] Ochiai, K., Kuppusamy, S., Yasui, Y., Harada, K., Gupta, N.R., Takahashi, Y., Kubota, T., Kobayashi, J.-I. and Hayashi, Y. (2016) Total Synthesis of 7,10-Epimer of the Proposed Structure of Amphidinolide N, Part II: Synthesis of C17-C29 Subunit and Completion of the Synthesis. Chemistry: A European Journal, 22, 3287-3291. https://doi.org/10.1002/chem.201504675 